\title{
PENGARUH PEMBERIAN Curcuma xanthoriza Roxb TERHADAP PERBAIKAN KERUSAKAN SEL HEPAR
}

\author{
Syafitri ${ }^{1}$ \\ ${ }^{1}$ Program Pendidikan Dokter, Fakultas Kedokteran, Universitas Lampung
}

\begin{abstract}
The Efficacy of Curcuma xanthoriza Roxb for Repairing Liver Cell Damage. Chronic hepatitis is one of the big problems facing the world, including in Indonesia. Chronic hepatitis can progress to progressive cirrhosis and eventually liver cancer in $20-30 \%$ of cases. Hepatitis pathophysiologically will cause cell damage to the liver. Hepatoprotector is a drug compound that can provide protection to the liver from damage caused by poisons, drugs, and others. Turmeric is one of the herbs that can be used as an alternative treatment because of its components such as curcumin (diferuloylmethane), demetoxycurcumin, bisdemetoxycurcumin and many other active substances. Curcumin in ginger has been studied to prevent liver cell damage. The mechanism of curcumin in protecting liver cells from damage is in line with the effect of curcumin as an antioxidant. Curcumin will capture superoxide ions and break the chain of ions between superoxide $\left(\mathrm{O}^{2-}\right)$, which in turn will process lipid peroxidation to prevent liver damage mediated by antioxidant enzymes, Superoxide Dismutase (SOD). SOD enzymes will convert $\mathrm{O}^{2-}$ to less toxic products. In addition, the mechanism of curcumin in preventing liver cell damage is also by increasing glutathione $S$ transferase (GST) and inhibiting several proinflammatory factors such as nuclear factor-kB (NF-kB) and profibrotic cytokines. Turmeric can prevent liver cell damage.
\end{abstract}

Keywords: Curcumin, Hepatitis, Hepatoprotector, Turmeric

Abstrak: Pengaruh Pemberian Curcuma xanthoriza Roxb terhadap Perbaikan Kerusakan Sel Hepar. Hepatitis kronis merupakan salah satu masalah besar yang dihadapi dunia termasuk di Indonesia. Hepatitis kronis dapat berkembang menjadi progresif yang menjadi awal terjadinya sirosis hati dan akhirnya kanker hati pada 20-30 \% kasus. Hepatitis secara patofisiologi akan menyebabkan kerusakan sel pada hati. Hepatoprotektor adalah suatu senyawa obat yang dapat memberikan perlindungan pada hati dari kerusakan yang ditimbulkan oleh racun, obat, dan lain-lain. Temulawak diteliti dapat berperan sebagai hepatoprotektor. Temulawak adalah salah satu tanaman herbal yang dapat dijadikan alternatif pengobatan karena komponen didalamnya seperti curcumin (diferuloylmethane), demetoxycurcumin, bisdemetoxycurcumin serta banyak zat aktif lainnya. Mekanisme kurkumin dalam menjaga sel-sel hepar dari kerusakan yaitu sejalan dengan efek kurkumin sebagai antioksidan. Kurkumin akan menangkap ion superoksida dan memutus rantai ion antar superoksida $\left(\mathrm{O}^{2-}\right)$ yang pada akhirnya proses peroksidasi lipid ini akan mencegah kerusakan hepar yang dimediasi oleh enzim antioksidan yaitu Superoxide Dismutase (SOD) dimana enzim SOD akan mengonversi $\mathrm{O}^{2-}$ menjadi produk yang kurang toksik. Selain mekanisme tersebut, mekanisme kurkumin dalam mencegah terjadinya kerusakan sel hepar yaitu juga dengan meningkatkan glutathion S-transferase (GST) dan menghambat beberapa faktor proinflamasi seperti nuclear factor-kB (NF-kB) dan profibrotik sitokin. Temulawak dapat mencegah kerusakan sel pada hepar.

Kata kunci: Hepatitis, Hepatoprotekor, Kurkumin, Temulawak 


\section{PENDAHULUAN}

Baru-baru ini, tanaman herbal
banyak dipergunakan sebagai
alternatif untuk mengobati beberapa
penyakit, salah satunya adalah
penyakit hati. Bahan-bahan herba
yang biasa digunakan untuk alternatif
pengobatan : bawang putih, seledri,
bawang merah dan temulawak (Purwaningsih, 2016). Hepatitis adalah salah satu penyakit yang dapat terjadi pada hati. Hepatitis kronis merupakan salah satu masalah besar yang dihadapi dunia termasuk di Indonesia. Hepatitis kronis dapat berkembang menjadi progresif yang menjadi awal terjadinya sirosis hati dan akhirnya kanker hati pada 20-30 $\%$ kasus. Penyebab hepatitis kronis yang terbanyak adalah virus hepatitis B dan virus hepatitis C (Ariswati, Siswanto, dan Hartanti, 2011).

Tujuan pengobatan hepatitis kronis adalah untuk mengurangi peradangan hati dengan cara menghilangkan atau menekan replikasi virus penyebab hepatitis, sehingga kerusakan hati dapat diminimalisir dan tidak berlanjut menjadi lebih parah. Karena sampai saat ini belum ada terapi yang optimal (biaya terapi mahal, efek samping yang serius dan tidak dapat mencegah rekurensi penyakit) untuk mengobati penyakit ini, maka para ahli mencoba terapi alternatif seperti terapi herbal (Candra, 2013).

Sampai saat ini belum ada obat yang disetujui sebagai hepatoprotektor, tetapi untuk tanaman-tanaman obat yang kini dipasarkan menjadi jamu atau campuran jamu yang dipasarkan di Indonesia telah diakui sebagai hepatoprotektor, misalnya Hepasil dari Kalbe Farma, Hepacomb dari Sidomuncul, Hepagard dari Phapros, dan berbagai produk lainnya (Sutriana et al, 2010). Salah satu bahan herbal yang pernah diteliti dapat bermanfaat sebagai hepatoprotektor adalah temulawak (Candra, 2013). Temulawak

(Curcuma xanthorhiza Roxb) adalah salah satu tumbuhan obat keluarga

Zingiberaceae yang banyak tumbuh dan digunakan sebagai bahan baku obat tradisional di Indonesia (Dwi Marinda, 2014). Temulawak dapat dimanfaatkan sebagai pewarna alami pada pengolahan makanan serta sebagai salah satu bahan untuk pembuatan jamu tradisional. Temulawak dikenal sebagai antitumor, antioksidan, obat malaria dan juga dapat mencegah tertularnya HIV pada manusia karena kandungan kurkumin didalamnya. Dengan mengekstrak kukurmin dari temulawak tentu penggunaan temulawak untuk pengobatan pasti akan lebih baik lagi (Hadipoentyanti dan Syahid, 2010).

Tanaman temulawak juga dikenal bermanfaat dalam pengobatan tradisional terhadap berbagai penyakit pada hepar (Candra, 2013). Saat ini kita mengenal berbagai bahan yang dinyatakan dapat mencegah dan mengobati penyakit hepatitis. Bahanbahan herbal yang digunakan sebagai antihepatitis antara lain meniran (Phyllanthus niruri, Linn), temu lawak (Curcuma xanthorrhiza Roxb), mengkudu (Morinda citrifolia $L$ ) dan pegagan (Centella asiatica $L$ ) (Rakhmad, 2017). Meskipun berdasarkan manfaat hepatoprotektif dari curcumin yang dapat dijadikan alternatif pengobatan pada pasien hepatitis kronis, tulisan ini merupakan review dari berbagai sumber jurnal dan penelitian terbaru yang relevan (Mutiah,2015).

\section{METODE}

Metode yang digunakan dengan mengumpulkan data sekunder yang sudah tertera pada sitasi dan daftar pustaka.

\section{HASIL DAN PEMBAHASAN}

Hati atau hepar adalah salah satu organ terbesar yang berada dalam rongga perut. Hati pada tubuh manusia mempunyai beberapa fungsi yaitu antara lain sebagai metabolisme karbohidrat dengan cara menyimpan glikogen dalam jumlah besar lalu 
mengkonversinya hingga menjadi glukosa. Selain metabolisme karbohidrat, fungsi hati yang lain adalah metabolisme lemak dan protein. Selain dari yang sudah disebutkan diatas, fungsi hati juga sebagai tempat penyimpanan vitamin dan besi serta juga sebagai membentuk zat-zat yang digunakan untuk koagulasi darah, mengeksresikan obat-obatan, hormon dan zat-zat lain (Ramdja, Aulia dan Mulya, 2009).

Hepatitis adalah salah satu penyakit yang dapat terjadi pada hati. Hepatitis kronis merupakan salah satu masalah besar yang dihadapi dunia termasuk di Indonesia. Hepatitis kronis dapat berkembang menjadi progresif yang menjadi awal terjadinya sirosis hati dan akhirnya kanker hati pada 20-30 \% kasus. Menurut Riset Kesehatan Dasar tahun 2013 mengatakan bahwa jumlah orang yang didiagnosis hepatits di fasilitas pelayanan kesehatan berdasarkan gejala-gejala yang ada, menunjukkan peningkatan dua kali lipat apabila dibandingkan dengan data 2007. Hal ini dapat memberikkan petunjuk awal kepada kita tentang upaya pengendalian di masa lalu, peningkatan akses, potensial masalah di masa yang akan datang apabila tidak segara dilakukan upaya-upaya yang serius (Kementrian Kesehatan Republik Indonesia, 2013).

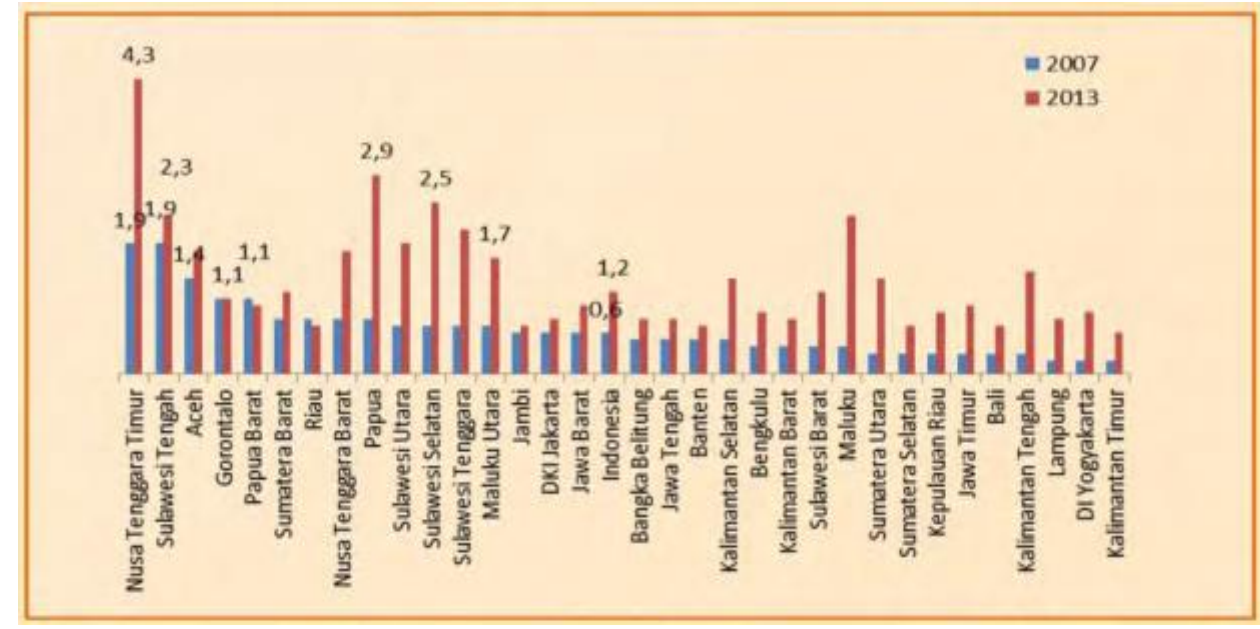

\section{Gambar 1. Prevalensi Hepatitis Menurut Provinsi 2007 dan 2013 (Kemenkes RI, 2013)}

Penyebab hepatitis kronis yang terbanyak adalah virus hepatitis B dan virus hepatitis C (Candra, 2013). Di Indonesia, hepatitis yang awalnya disebabkan oleh infeksi virus masih merupakan penyakit endemis. Karena dengan adanya kemajuan dalam pemeriksaan imunoserologis, jaman sekarang ini sudah dapat mendeteksi adanya virus hepatitis A sampai dengan $E$, sebagian penderita yang terinfeksi virus hepatitis $B, C$ dan $D$ akan menjadi kronis yang akan berlanjut menjadi sirosis dan kanker hati dan berakhir dengan kematian karena kegagalan fungsi organ hati yang terjadi (Retno, 2017).

Hepatoprotektor adalah suatu senyawa obat yang dapat memberikan perlindungan pada hati dari kerusakan yang ditimbulkan oleh racun, obat, dan lain-lain. Hati adalah organ yang unik, unit sel fungsionalnya yang bernama hepatosit bersifat tidak dapat memperbaharui selnya yang mengalami kerusakan. Meskipun begitu, selama sebagian besar sel hati berada dalam keadaan baik-baik saja maka organ hati dapat melakukan 
fungsinya secara utuh (Rosidi et al, 2011).

Temulawak atau dengan bahasa latin biasa disebut Curcuma xanthoriza Roxb merupakan salah satu tanaman rempah kekayaan bumi Indonesia yang telah lama manfaat dan khasiatnya diketahui sejak dahulu kala. Temulawak sebagaimana nama padananya, Curcuma javanica, telah diketahui negara-negara luar sebagai tumbuhan asli Indonesia, yang kemudian menyebar ke beberapa Negara lain, seperti Malaysia, Cina bagian selatan, Thailand, Birma, India, dan Fillipina (Sasoka, 2014).

Temulawak merupakan satu dari 19 jenis temu-temuan keluarga Zingiberaceae yang paling banyak digunakan sebagai bahan baku obat tradisional (Sutriana et al, 2010). Tumbuhan temulawak secara empiris banyak digunakan sebagai obat tunggal maupun campuran. Terdapat lebih dari dari 50 resep obat tradisional Indonesia yang bahan bakunya menggunakan temulawak (Dwi Marina, 2014). Tanaman temulawak juga dikenal bermanfaat dalam pengobatan tradisional terhadap beberapa penyakit pada hepar (Yasri, Hendry dan Febriona, 2018).

Dari penelitian terbaru diketahui bahwa bahan aktif dari berbagai spesies curcuma tersebut adalah curcumin. Curcumin (diferuloylmethane) adalah pigmen kuning yang banyak didapatkan dari isolasi spesies curcuma, zingiberaceae. Tulisan ini merupakan review dari berbagai sumber tulisan lain dan penelitian terbaru yang mendiskusikan tentang manfaat hepatoprotektif dari curcumin sebagai obat alternatif (Yasri, Hendry dan Febriona, 2018).

Senyawa lain yang ada dalam temulawak selain kurkumin antara lain adalah kurkuminoid, minyak atsiri, dan pati. Salah satu kandungan temulawak yaitu minyak atsiri dapat berguna sebagai agen peningkat proses apoptosis, antiinflamasi, antibakteri, dan antioksidan. Selain itu senyawa kurkumin pada temulawak mempunyai aktivitas hepatoprotektif yang berfungsi dalam mencegah penyakit hepar (Rosidi et al, 2011). Kurkumin dari temulawak dapat diambil dengan cara ekstraksi, ekstraksi adalah istillah yang digunakan untuk proses dimana suatu konstituen cair atau padat dipindahkan dicairan lainnya dimana solven yang digunakan adalah etanol (Hadipoentyanti dan Syahid, 2010).

Kurkumin adalah komponen fitokimia yang dapat kita temukan dalam kunyit. Curcumin juga digunakan sebagai obat dan ramuan tradisional untuk mengobati berbagai macam penyakit di beberapa Negara selain di Indonesia. Temulawak tidak hanya mengandung curcumin, namun juga mengandung analog curcumin antara lain demetoxycurcumin, bisdemetoxycurcumin serta banyak zat aktif lainnya. Perbandingan kandungan curcuminoid yang terkandung dalam kunyit adalah curcumin I 75\%, curcumin II (demetoxycurcumin) 16\%, dan curcumin III (bisdemethoxycurcumin) 8\% (Candra, 2013).

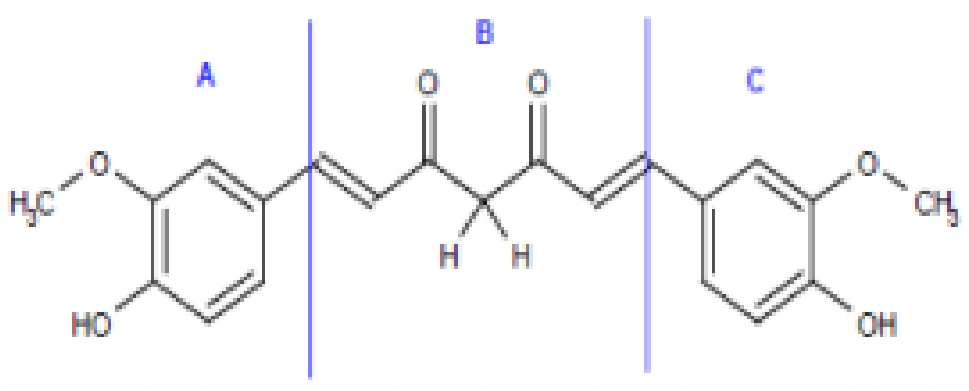

Gambar 2. Struktur Curcumin (Candra 2013). 
Penelitian yang dilakukan oleh Sirait (2014), menjelaskan bahwa pemberian dekok rimpang dapat mencegah kerusakan hepar tikus jantan dewasa galur Sprague dawley yang sebelumnya diberikan induksi aspirin. Pemberian dekok rimpang temulawak dengan dosis $2,6 \mathrm{~g} / \mathrm{kgBB}$ dan 5,2 $\mathrm{g} / \mathrm{kgBB}$ memiliki efek hepatoprotektif terhadap hepar tikus yang diinduksi aspirin lebih baik dibandingkan dengan kelompok yang hanya diberi dekok rimpang temulawak dosis $1,3 \mathrm{~g} / \mathrm{kgBB}$. Selain penelitian yang dilakukan oleh Sirait adapula penelitian dari Candra (2013) yang mengatakan bahwa pemberian temulawak pada kelompok tikus Wistar yang sebelumnya telah diinduksi paracetamol dosis toksik dapat mencegah terjadinya peningkatan kadar SGOT dan SGPT pada tikus tersebut. Pemberian temulawak mampu menurunkan nilai SGOT rata-rata 31 dan SGPT 9,3 (Rosidi et al, 2011).

Dari beberapa jurnal yang membahas tentang efek kurkumin, mekanisme kurkumin dalam menjaga sel-sel hepar dari kerusakan yaitu sejalan dengan efek kurkumin sebagai antioksidan. Kurkumin akan menangkap ion superoksida dan memutus rantai ion antar superoksida $\left(\mathrm{O}^{2-}\right)$ yang pada akhirnya proses peroksidasi lipid ini akan mencegah kerusakan hepar yang dimediasi oleh enzim antioksidan yaitu Superoxide Dismutase (SOD) dimana enzim SOD akan mengonversi $\mathrm{O}^{2-}$ menjadi produk yang kurang toksik (Candra, 2013) Selain mekanisme tersebut, mekanisme kurkumin dalam mencegah terjadinya kerusakan sel hepar yaitu juga dengan meningkatkan glutathion $S$ transferase (GST) dan menghambat beberapa faktor proinflamasi seperti nuclear factor- $k B$ (NF-kB) dan profibrotik sitokin (Rosidi et al, 2011).

Dari penelitian sebelumnya dikatakan bahwa kombinasi kurkumin dengan lamivudine akan menekan aktivitas virus hepatitis $B$ lebih efektif dibandingkan hanya diberikan lamivudine saja (Yunarto, 2013). Dari pembuktian klinis didapatkan pula bahwa penggunaan kurkumin dosis tinggi (1000-2000 mg/hari) tidak menyebabkan efek yang berbahaya bagi tubuh. Maka dari itu kurkumin yang terkandung dalam temulawak akan berpotensi tinggi menjadi alternative pengobatan khususnya penyakit hati dimasa yang akan datang (Candra, 2013)

\section{RINGKASAN}

Hepatitis adalah suatu penyakit yang disebabkan oleh virus yang pada akhirnya akan menyebabkan kerusakan pada hati. Temulawak dapat dijadikan alternatif pengobatan karena salah satu komponennya yaitu kurkumin. Kurkumin dalam temulawak dapat mencegah kerusakan sel hati dengan cara menangkap ion superoksida dan memutus rantai ion antar superoksida $\left(\mathrm{O}^{2-}\right)$ yang pada akhirnya proses peroksidasi lipid ini akan mencegah kerusakan hepar yang dimediasi oleh enzim antioksidan yaitu Superoxide Dismutase (SOD) dimana enzim SOD akan mengonversi $\mathrm{O}^{2-}$ menjadi produk yang kurang toksik. Selain mekanisme tersebut, mekanisme kurkumin dalam mencegah terjadinya kerusakan sel hepar yaitu juga dengan meningkatkan glutathion $S$ transferase (GST) dan menghambat beberapa faktor proinflamasi seperti nuclear factor-kB (NF-kB) dan profibrotik sitokin.(Dwi Marinda, 2014) Hal ini juga diperkuat buktinya dengan ` penelitian tentang temulawak dan dikatakan bahwa kurkumin pada temulawak dengan dosis $1600 \mathrm{mg} / 200 \mathrm{mgkgBB}$ dapat berefek hepatorepair lebih baik daripada dosis $400 \mathrm{mg} / 200 \mathrm{mgkgBB}$ dan $600 \mathrm{mg} / 200 \mathrm{mgkgBB}$ pada tikus Wistar.

\section{KESIMPULAN}

Sifat antioksidan kurkumin dalam temulawak dapat mencegah kerusakan sel hepar. 
DAFTAR PUSTAKA

Ariswati W C, Siswanto A, \& Hartanti D. (2011). Pengaruh Gelatin, Amilum dan PVP Sebagai Bahan Pengikat Terhadap Sifat Fisik Teblet Ekstrak Temulawak (Curcuma Xanthorrhiza, Rxob). Pharmacy. 13(02):58-66.

Candra, A. (2013). Aktivitas Hepatoprotektor Temulawak pada Ayam yang Diinduksi Pemberian Parasetamol Hepatoprotector Activity of Curcuma in Chickens was Induced By Paracetamol. Jurnal Penelitian Pertanian Terapan. 13(2): 137-143.

Daulay DG, Supriatmo S, \& Sinuhaji AB. (2013). Hepatitis Akibat Penyakit Sistemik. Sari Pediatri. 8(4):294-8.

Dwi Marinda F. (2014). Hepatoprotective Effect of Curcumin in Chronic Hepatitis. Majority J. 3(7):52-6.

Hadipoentyanti $E$, \& Syahid SF. (2010). Respon Temulawak (Curcuma xanthorrhiza Roxb.) Hasil Rimpang Kultur Jaringan Generasi Kedua Terhadap Pemupukan. Jurnal Littri. 13(3):106-110.

Hendrarahardja. (2003). Hepatitis Viral Akut, in: Buku Ajar IImu Penyakit Dalam. 1 st ed. Jakarta: Balai Penerbit FKUI pp. 253-8.

Kemenkes RI. Riset Kesehatan Dasar 2013. (2013). Jakarta: Kemenkes RI.

Marwita SPR. (2013). Si "Kuning" Temulawak (Curcuma xanthoriza Roxb.) Dengan "Segdang" Khasiat. Jurnal Tekonologi Pertanian. 2(2): 42-9.

Mutiah R. (2015). Evidence Based Kurkumin Dari Tanaman Kunyit (Curcuma longa) Sebagai Terapi Kanker pada Pengobatan Modern. Jurnal farma Sains. 1(1):25-41

Purwaningsih E. (2016). Potensi
Kurkumin Sebagai Bahan Anti Fertilitias. Jurnal kedokteran yarsi. 24(3);203-211

Rakhmad, W. (2017). Studi Pembuatan Serbuk Effervescent Temulawak (Curcuma xanthorrhiza roxb) Kajian Suhu Pengering, Konsentrasi Dekstrin, dan Na-bikarbonat. Jurnal Teknologi Pangan. 1(1):1-31.

Ramdja AF, Aulia RMA, \& Mulya P. (2009). Ekstraksi Kurkumin Dari Temulawak Menggunakan Etanol. Jurnal Teknik Kimia. 16(3): 528.

Retno Mashita A. (2017). Efek Antimikroba Ekstrak Rimpang Temulawak (Curcuma xanthorrhiza) Terhadap Pertumbuhan Staphylococcus aureus. Saintika Medika. 10(2):138.

Rosidi A, Khomsan A, Setiawan B, Riyadi H, \& Briawan D. (2010). Potensi Temulawak (Curcuma xanthorrhiza Roxb ) Sebagai Antioksidan. Program Studi Gizi.

Sasoka DS. (2014). Hubungan Antara Higiene Perseorangan Dengan Kejadian Hepatitis A Pada Pelajar / Mahasiswa. Jurnal Berkala Epidemiologi. 2(3):331-341.

Sutriana A, Aliza D, Vanda $H$, \& Rahmi E. (2010). Aktivitas Hepatoprotektif Ekstrak Etanol Daun Kucing-kucingan Acalypha indica L.) pada Tikus Putih (Rattus Novergicus) yang Diinduksi Parasetamol. Jurnal Ilmiah Ilmu-Ilmu Peternakan. 13(6):292-8.

Yasri D, Hendry W, Febriona S. (2018). Hubungan Pengetahuan, Ketersediaan Sarana Dengan Pencegah Hepatitis B Pada Perawat di Rumah Sakit Ibnu Sina Bukittinggi. Afiyah. 2:52-8.

Yunarto N. (2013). Prospek Tanaman Obat sebagai Antihepatitis. Jurnal Kefamasian Indonesia. 3(2): 609. 